司会のことば

\begin{abstract}
鹿児島大学医学部 耳鼻咽喉科
島根医科大学 耳鼻咽啹科

黒野 祐一

川内 秀之
\end{abstract}

第 40 回日本鼻科学会 (馬場廣太郎) は、基礎問題研究 会のシンポジウムのテーマに『鼻アレルギーの感作と発 症に関する因子』をとりあげられ、鹿児島大学の黒野祐 一教授とともに司会の任を受けた。相談のうえ、シンポ ジストとして、大阪市立大学の大橋淑宏先生、山梨医科 大学の松崎全成先生、岡山大学の岡野光博先生、獨協医 科大学の盛川 宏先生の 4 人の先生方を選ばせていただ いた。鼻アレルギーの感作と発症にどのような因子が絡 んでいるのかを各々の領域でスペシャリストとして活躍 されている先生方に解説いただくとともに、研究の手 法・内容・将来展望について、忌憚のないところをお話 いただくことにした。

進行の順にしたがって紹介させていただくと、(1)岡野 先生には、「感作成立に関与する外的因子の検討」と題し て、細菌抗原の感作への影響や、アレルゲン自体が有す る糖鎖の構造が外的因子として感作に関わるという点に ついて講演をいただく。(2)松崎先生には、「感染症の面か ら」と題して、寄生虫感染・ウイルス感染・結核と I 型 アレルギー疾患とくに鼻アレルギーの成立の関係につい て、詳細な検討結果をまとめていただく。(3)盛川先生に は、「鼻アレルギーにおける costimulatory signal の役割 一ルパーT細胞の分化に対する役割一」と題して、ヒ ト末梢血リンパ球を用いた検討により、スギ花粉抗原刺 激を行ったスギ花粉症患者の末梢血単核球に表出される costimulatory molecule（補助刺激分子）の解析と産生 されるサイトカインについて詳細の報告。さらに、抗 CD86（Th2 タイプのリガンド）抗体や抗 CD40 抗体を 用いて blocking 試験を行い、スギ花粉特異的な細胞増殖 やTh1あるいはTh2タイプのサイトカイン産生に及ぼす costimulatory molecule の影響を検討した結果について 言及していただく。(4)大橋先生には、「免疫療法による感 作と発症の予防」と題して、先生が長年にわたって蓄積 してこられた免疫療法の成果について、(1)スギ花粉に感 作される局面において、通年性鼻アレルギーに対して行 われたダニ免疫療法が予防的に作用しているという話題
と、(2)スギ花粉に感作されているが発症していない通年 性（ダニ）鼻アレルギー患者に対して行った、ダニ抗原 とスギ花粉併用免疫療法が、スギ花粉症発症に予防的に 作用したという結果を、未梢血単核球のサイトカイン産 生のデータとともに紹介していただく。

シンボジウムのはじめに、鼻アレルギーの病態、アレ ルギー性炎症や感染性炎症に関わるヘルパーT 細胞サイ トカイン産生、抗原提示細胞の costimulatory molecule (補助刺激分子) などを簡潔に整理したうえで、各シン ポジスの専門的な講演を拝聴し、最後に総合討論と今後 の展望についてまとめることで、責任を果たしたいと考 えている。 
感作成立に関与する外的因子の検討

岡山大学大学院 耳鼻咽喉・頭頚部外科学 ○岡野光博

【はじめに】鼻粘膜は外的環境に直面する生体防御の First line である。従って、鼻粘膜微小環境へのアレ ルゲンを含めた大気内浮遊物質の作用は、鼻アレルギ 一の感作成立に大きく影響をおよぼす。最近、いくつ かの疫学調査により感染とアレルギ一感作との関連が 注目されるようになった。今回我々は、独自に開発し たマウス鼻アレルギーモデルを用いて、細菌抗原の感 作への影響を検討した。さらにアレルゲンの抗原性自 体も大きな外的因子のひとつであると考えられるので、 今回は抗原を構成する糖鎖の感作成立への影響につい ても検討した。

【方法】BALB/cマウスにアジュバントを用いずマン ソン住血吸虫卵抗原 (SEA) を繰り返し点鼻感作するこ とにより、SEA特異的IgEの産生、鼻粘膜内好酸球浸 潤、および鼻粘膜リンパ球のIL-4・IL-5産生を指標と する鼻アレルギ一感作を誘導した。点鼻感作時に結核 菌由来の抗原であるPPD、あるいは黄色ブドウ球菌の 外毒素であるSEBを経鼻投与し、感作動態の変化を観 察した。さらにSEAを構成する糖鎖はペリオデートに て破壊した。天然型およびペリオデート処理SEAの点 鼻感作による感作動態の相違を観察した。

【結果】 PPDを単回点鼻投与した場合、鼻粘膜内に IFN- $\gamma$ シグナルの増強が確認された。PPDをSEA点鼻 感作時に経鼻投与すると、SEA特異的IgE産生抑制、

鼻粘膜好酸球浸潤抑制、および鼻粘膜リンパ球のIFN$\gamma$ 産生の亢進がみられた。一方、鼻粘膜リンパ球はSEB 刺激に対してIL-4産生を誘導した。SEA点鼻感作時に SEBを経鼻投与すると、PPDの場合とは逆にSEA特異 的IgEの産生六進、鼻粘膜内好酸球浸潤亢進、および

鼻粘膜リンパ球のIL-4産生六進がみられた。またペリ オデート処理SEAにて点鼻感作した場合、天然型SEA に比較して、感作動態は有意に抑制された。

【結論】細菌抗原は、感作にポジティブあるいはネガ ティブな影響を与える外的因子の一つと考えられた。 さらにアレルゲン自体の構造、特に構成糖鎖が感作成 立に大きく関与することが示唆された。
鼻アレルギーの感作と発症に関する因子 一感染症の面からー

山梨医科大学耳鼻咽喉科

$\bigcirc$ 松崎全成

近年その増加が大きな問題となっている鼻アレルギ 一であるが、この発症には、他の疾患同様、遺伝要因 と環境要因が関与すると考えられている。一方、 CD4Thelper 細胞の Th1 サイトカイン、Th2 サイトカ インのアンバランスがアレルギーの疾患の根底にある ことが指摘され、鼻アレルギーにおいても Th1 に比較 して Th2 サイトカイン産生が有意に六進していること を示す報告がされているが、発症要因もこれらのサイ トカイン産生に影響を及ぼしていると考えられている。 環境要因のひとつとしてウイルス・寄生虫・結核など 感染症の関与も取り上げられ、例えば結核や麻疹は Th1 サイトカインを誘導する代表的感染症として知ら れ、このような感染症罹患の減少がアレルギー疾患の 増加と関連しているとの報告がある。一方、感染症の なかでも蠕虫感染や気道ウイルス感染の中には Th2 サ イトカインの誘導に作用するものが知られている。特 に蠕虫感染は強力な IgE 誘導能が知られているが、先 進国での蠕虫感染の減少が、むしろアレルギー抗原に 対する IgE 産生誘導や発症に影響しているといつた報 告もある。鼻アレルギーの病態においても確かに Th1/Th2 サイトカイン産生のアンバランスの一面は あるが、単純に病態をすべて物語るものでもない。例 えば、感作マウスでの Th1 サイトカインの誘導はア レルギーの症状や病像をむしろ増悪に働きうる。また 鼻アレルギーの感作と発症といった問題をそれぞれ別 個に考えていく必要もあろう。

鼻アレルギーの感作、発症に関する因子として、感 染症の面から自験例もまじえて考察を加えて問題点も 明らかにしたい。 
鼻アレルギーにおける costimulatory signal の役割

一ヘルパー T細胞の分化に対する役割—

\section{獨協医科大学 耳鼻咽喉科気管食道科学教室}

盛川宏

【はじめに】鼻アレルギーなどの I 型アレルギーの病態 形成にはヘルパーT細胞のうち Th2 が重要な役割を果た していると考えられている。ナイーブT細胞が活性化さ れ Th2 へと分化するには、第 1 シグナルとともに第 2 シ グナル (costimulatory signal) が必要と考えられている。 スギ花粉症における costimulatory 分子の関与について 検討した。

【対象および方法】花粉症患者 12 名、健常者 10 名につ いてスギ花粉抗原刺激により末梢血単核球 (PBMC) 上 に表出される各 costimulatory 分子と、培養上清中のサ イトカインのパターンを健常者とスギ花粉症患者とで比 較した。さらに costimulatory 分子の関与をより明確に するため、花粉症患者 7 名について中和抗体を用いた blocking 試験を行った。

【結果】 PBMC をスギ花粉抗原で刺激するとスギ花粉症 患者においては、健常者に比べ CD19 陽性細胞上の CD86、CD40 が有意に強く発現された。培養上清中の IL-5 は花粉症患者で、IFN- $\gamma$ は健常者で有意に高かった。 IL-4 は花粉症患者、健常者ともに検出できなかった。抗 CD86 抗体、抗 CD40 抗体による blocking 試験を行った。 抗 CD86抗体添加群ではPBMCの細胞増殖能は抗体無添 加に比べ有意に抑制されたが、抗 CD40 抗体添加群では 一定の傾向を示さなかった。IL-5 の産生は抗 CD86 抗体 添加群では抗体無添加群に比べ有意に抑制された。IFN$\gamma$ の産生はいずれの群でも差はなかった。IL-4 はいずれ の群でも検出できなかった。

【考察】鼻アレルギーにおいてはヘルパーT 細胞のうち Th2 が優位となっており、Th2への分化に costimulatory signal のうち B7-2（CD86）を介する signal が重要な役 割を果たしている可能性が示唆された。
鼻アレルギーの感作と発症に関する因子

一免疫療法による感作と発症の予防一

大阪市立大学大学院医学研究科 上気道機能病態学 ○大橋淑宏

わが国におけるスギ花粉症の患者数は依然として増加 しており、スキ花粉に対する感作やスギ花粉症の発症 を予防することは極めて重要な課題である。そこで、 免疫療法によって感作や発症を予防し得ないか否かを 検討した。

1 ダニ免疫療法による感作予防

初診時にスキ花粉に感作されていなかった通年性アレ ルギー性鼻炎患者で、 2 年以上に渡ってスギ花粉に対 する感作の有無をC A P で観察し得た149名を対象とし た。このうち 41 名は免疫療法を施行せず、抗アレル ギー薬で鼻症状をコントロールした（薬物療法群）。 他の108名は標準化コナヒョウヒダニを用いた免疫療法 を施行した（免疫療法群）。薬物療法群では18名

（43.9\%）にスギ花粉に対する感作の獲得を認め、免 疫療法群では感作の獲得は27名（25.0\%）であった。 また、対象患者の年齢および観察期間を補正して検討 すると、薬物療法群では感作獲得率は35.9\%で、免疫 療法群では6.9\%と大きな有意差を認めた $(\mathrm{P}=$ 0.0005）。したがって、標準化ダ二抗原を用いた免疫 療法はスギ花粉に対する感作を予防しうると考えられ る。

2 感作成立個体に対する発症予防

通年性アレルギー性鼻炎患者でスギ花粉に感作されて いるが発症していない67名を対象とた。このうち 32 名 は標準化ダ二抗原単独の免疫療法を施行中で（経過観 察群）、35名はダ二抗原の免疫療法に加えて予防的な スギ花粉免疫療法を施行していた（䂆防治療群）。経 過観察群では7名 (21.9\%) が2000年のスギ花粉飛散 期にスギ花粉症の発症を認めたが、予防治療群ではス ギ花粉症の発症を認めなかった。また、予防治療群で は無症候性スギ花粉症の特徴であるせ-4産生の元進が 抑制されていた。

以上の成績からスギ花粉に対する感作の獲得や発症 は免疫療法によって䂆防しうることが可能であると考 えられる。 